\title{
Perceptions Held by Finnish Energy Sector Experts Regarding Public Attitudes to Energy Issues
}

\author{
Noora Valkila ${ }^{1} \&$ Arto Saari $^{1}$ \\ ${ }^{1}$ School of Engineering, Aalto University, Helsinki, Finland \\ Correspondence: Noora Valkila, School of Engineering, Aalto University, Helsinki, PO Box 12100, FI - 00076 \\ Aalto, Finland. Tel: 358-500-405-446. E-mail: noora.valkila@aalto.fi
}

Received: August 21, 2012 Accepted: September 27, 2012 Online Published: October 18, 2012

doi:10.5539/jsd.v5n11p1 URL: http://dx.doi.org/10.5539/jsd.v5n11p1

\begin{abstract}
The aim of this study was to examine Finnish attitudes to energy issues by means of a qualitative interview survey of selected energy sector experts. Based on the analysis of the results, conclusions were made about aspects of the perceived public attitudes to energy issues. Also how these may be activated and manipulated. Citizens with neutral energy attitudes constitute the most critical group, according to the interviewees. They also felt that Government action is the most effective means for influencing attitudes, and that these means should be deployed urgently. Other means include peer groups, information provision, the media, upbringing/education and imagery/visions. The study offers a new approach to understanding public attitudes to energy issues and the impact of these attitudes by documenting the views of a selection of the country's energy sector experts as individuals.
\end{abstract}

Keywords: Finnish energy policy, energy attitudes, energy sector experts, influencing attitudes

\section{Introduction}

Attitudes, whether those of consumers, political decision-makers, corporate energy-sector management or other energy experts, undoubtedly have an influence on production and consumption decisions in the energy sector. Decisions on energy issues are frequently made not on a purely rational basis but are influenced by opinions and perceptions, especially where matters of policy are concerned (Lorenzoni \& Pidgeon, 2006; Van der Horst, 2007; Ruostetsaari, 2010). Technology solutions within the existing energy sector will not by themselves change the sector dramatically enough to ensure achievement of the targeted goals for controlling climate change (Darby, 2006). National governments are responsible for ensuring appropriate legislation and supervision to guarantee that good quality energy is produced on a continuous basis in order that societies can grow while adhering to sustainable development principles (Peattie, 2002; Soyhan, 2009).

The study presented here involved interviews with eight Finnish experts whose work involves consideration of energy issues. These energy sector experts were selected on a random sampling basis from objectively predefined units. A key principle of the new approach followed in this study was to make use of a variety of methodologies and approaches in the field of environmental and societal transitions.

This study sought to address the following questions: 1) What characteristics can be observed in current Finnish attitudes to energy issues? 2) What are the consequences of a change in attitudes, and is this accompanied by a change in behaviour? 3) What are the most effective means for influencing people's attitudes?

To help answer these questions, selected energy sector experts were asked to present their personal views concerning attitudes in Finnish society in general towards energy issues. These views cannot be taken as representative of society as a whole but instead seek to define or expand on different aspects of Finnish attitudes to energy issues.

The authors decided to approach Finnish attitudes to energy issues by means of a qualitative study of eight Finnish experts whose work involves consideration of energy issues. Since attitudes and behaviour are often considered to be only loosely related to each other when it comes to energy use in Finland, the authors sought to examine more closely the role of attitudes in influencing the energy behaviour of Finns. The main aim was to identify Finnish attitudes to energy issues and discuss how these attitudes can be modified. A further aim was to study the perceived impressions of eight Finnish experts regarding the general position taken in Finnish attitudes 
to energy issues.

Values are closely related to attitudes: they guide the individual's thinking, choices and actions. A person's attitudes reflect his/her values. Attitudes are made up of cognitive, emotional and functional elements. A consumer's knowledge of a particular company may influence his/her feelings and actions (Allard, 1983; Rannikko, 1995; Bergström \& Leppänen, 2007). If attitudes towards greater efficiency in energy use are to be improved, it is extremely important that people's quality of life should not be adversely affected by such efficiency measures (European Commission, 2008). Modifying attitudes is a complex field, however, and the concept of "quality of life" can be defined in varying ways. Measurement of attitudes and quality of life can also be performed in different ways.

Environmental protection and ecology are the key values of sustainable development. Most definitions of sustainable development include reference to development, equity and the environment. In the United States, research work by the Board on Sustainable Development of the National Research Council (1999) has begun to focus on the concept of a sustainability transition and the needs of a stabilizing future world population.

Sustainability values are often expressed through specific attitudes and behaviour. Surprisingly, there is no survey data on public attitudes towards sustainable development as a holistic concept. However, empirical data related to many of the sub-components of sustainable development does exist.

Several surveys have measured global environmental attitudes regarding the intrinsic value of nature, global environmental concerns, the trade-offs between environmental protection and economic growth, government policies, and individual and household behaviour (Leiserowitz et al., 2006). Energy attitudes have become greener worldwide (Oktay et al., 2009).

Alongside the environmental viewpoint, the concept of consumption has broadened to include 'ethical consumption', which takes extensive account of the ethical and moral perspectives on production and distribution (Auger \& Devinney, 2007). Ethical consumption is motivated and guided by attitudes. Ethical consumers can be divided into four different groups on the basis of ethical awareness and the desire to make ethical consumption choices. The four different categories are shown in the following matrix (Figure 1).

Ethical awareness

\begin{tabular}{|c|c|c|c|}
\hline \multirow{3}{*}{ Ethical consumption choices } & & High & Low \\
\hline & High & $\begin{array}{c}\text { Caring and } \\
\text { ethical }\end{array}$ & $\begin{array}{l}\text { Confused and } \\
\text { uncertain }\end{array}$ \\
\hline & Low & $\begin{array}{l}\text { Cynical and } \\
\text { reckless }\end{array}$ & Ignorant \\
\hline
\end{tabular}

Figure 1. Consumer attitudes to ethical procurement (Atalla \& Carrigan, 2001)

The caring and ethical consumer is interested in differentiating between ethical and non-ethical companies and in responding favourably towards genuine socially responsible actions. Consumers who are confused and uncertain may wish to make ethical consumer choices but are puzzled when confronted with a host of conflicting information on the socially responsible nature of companies. Cynical and reckless consumers may be aware of ethical issues but are unconvinced that companies are really acting in a socially responsible manner. Ignorant consumers, on the other hand, are impeded by not having information that could lead them to increase the role of ethical factors in their choice criteria (Attalla \& Carrigan, 2001).

Each one of us processes and understands information in our own way, which naturally means a very wide range of views on the importance and nature of energy issues. Most people have an innate desire to see their own descendants survive and prosper, and this motivates their wish to curb climate change in the interests of future generations (Peattie, 2002). As cognitive organisms of the same species, we process information in similar ways, yet the combinations of these processes allow for considerable variation in our more abstract reasoning (Dennett, 1991).

It is also widely concluded that a person's sex and educational background in particular will affect his/her attitudes. Indeed, many studies have found that a more favourable attitude towards the environment and energy issues is displayed by women (Hawthorne \& Alabaster, 1999; Tikka et al., 2000; Tulokas, 2002; Eisler et al., 2003 ) and by more highly educated groups (Hawthorne \& Alabaster, 1999; Mikkola, 2001). Studies have also 
found that people who generally welcome innovations also adopt ethical consumption habits more readily and rapidly than those who 'trail behind' (Auger \& Devinney, 2007).

Finnish attitudes to environmental and energy issues have been monitored on an irregular basis since the 1970s, and systematically since 1983 (Kuisma, 2001). In the 1980s, Finns began to consider more closely the relationship between consumption, energy and the environment (Tulokas, 2002). An 'ecologicalisation' has occurred throughout Finnish society since the climate change threat became real. Attitude surveys undertaken in the mid and late 1990s indicate that support for environmental protection and for increased information provision on energy issues had already become the social norm by that time (Sairinen, 1996; Tulokas, 1998). Concern has also grown, and there is support for fundamental changes in lifestyle (Omer, 2008; Thøgersen \& Crompton, 2009). Even the number of people regarding solutions to environmental problems as more important than economic growth has grown significantly, and people are ready to make economic sacrifices for a better environment (Uusitalo, 1991; Tulokas, 2004). In particular, greater awareness of energy consumption is boosting interest in personal consumption monitoring and in reducing overall energy consumption (Aho et al., 2006).

The problem still remains that favourable attitudes do not always lead to concrete action to control climate change. Likewise, positive attitudes towards environmental protection do not necessarily give rise to any kind of political movement (Leiserowitz et al., 2006). Many research studies have identified critical gaps and barriers between expressed values or attitudes and actual behaviour, at both the individual and the collective level (Blake, 1999; Kollmuss \& Agyeman, 2002; Stern, 2000). However, there are differences of opinion over the relative responsibilities of the different actors (individuals, communities, business, government, environmental groups) and over the most effective means to translate environmental concern into pro-environmental behaviour and thus overcome the 'value-action gap' (e.g. Eden, 1993; Harrison et al., 1996; Hinchliffe, 1996; Burgess et al., 1998).

Publicly available information on energy issues is reported as being in surprisingly short supply and some of it is conflicting (Brand, 1997; Blowfield et al., 2001; Kuisma, 2001; Lybäck, 2002; Neergaard \& Pedersen, 2006). For many people, energy saving automatically conjures up the idea of fewer comforts and a lower quality of life (Aho et al., 2006). Consumers find it difficult to see the concrete benefits of their own individual energy savings (Dearing, 2007; Ministry of Trade and Industry, 1994). Finland has proved to be a good example of a country where there is a clear conflict between green attitudes and people's behaviour (Lybäck, 2002). The weak linkage between attitudes and actions has been explained by, for instance, the ease of taking an onlooker's role when faced with complex climate issues (Retallack et al., 2007).

The assumption that attitudes can influence people's environmental behaviour has been critically examined. People often behave in a complete information vacuum, daily routines tend to control behaviour, and the cultural framework within which we live guides our choices along familiar paths. Indeed, the attitude-behaviour paradigm takes no account of the interaction between people's behaviour and the structures of society or micro-level factors and processes (Massa \& Haverinen, 2001). What is more, attitudes are not formed in isolation from the rest of life but are likely to be affected by a host of different factors and competing viewpoints (Erwin, 2001). Although studies show that the link between attitudes and behaviour is not a strong and direct link, favourable environmental attitudes are nevertheless likely to have some effect on behaviour via feelings of moral responsibility, a wish to identify with the role of green consumer, and through social norms (Moisander, 1996).

Belt-tightening in the current tough economic climate may well have diminished people's appetite for greening their lives. According to a recent opinion survey $(n=1,000)$, Finns are less willing than before to take steps to prevent climate change if they have to pay for them (Gallup Finland, 2009). The same survey found that only about one third of respondents would be prepared to pay a so-called climate tax on the prices of products and services, although just six months earlier the figure was 45 per cent. Less than one in five would be in favour of a marked increase in energy prices for environmental reasons. On the other hand, the survey indicated that Finns believe they have already done a lot to curb climate change.

The Finnish experts interviewed in the present study cite the recession as an explanation for this decline in the willingness to make sacrifices: in a weakened economy there is less desire and less capacity to make further sacrifices. Other factors believed to be influencing people's attitudes are the media, recent weather patterns and green actions already taken (Sippola, 2009).

In today's world, the corporate image of companies, and their social responsibility in particular, has become increasingly important to Finnish consumers (Iwanow et al., 2005). An extensive survey of Finns found that 45 per cent regarded corporate social responsibility as a significant factor influencing purchase decisions (Haapala $\&$ Aavameri, 2008). The reliability of energy information produced by companies is nevertheless questioned. In enquiring the views of over 2,000 Finns on the reliability of corporate information concerning ethical matters, 
more than one third (35.3 per cent) of respondents felt that such information is fairly unreliable, while 2.0 per cent considered it to be extremely unreliable (Uusitalo \& Oksanen, 2004).

The view is sometimes expressed that Finland is on the margins of environmental and energy policy problems. It is felt to be unaffected by the major threats, which are seen as largely a problem for the rest of the world. According to the results of one survey, 71 per cent of respondents were satisfied with the state of the environment in Finland, but very few (4 per cent) were satisfied with the state of the environment globally (Lybäck, 2002). This phenomenon has been explained by the fact that in Finland there is relatively little environmental damage of a significant scale and detectable with the senses, and this can distort people's impressions (Suhonen, 1994).

Most advocates of sustainable development recognise the need for changes in human values, attitudes and behaviour in order to achieve a transition towards sustainability. Energy attitudes held by the general public can be an important factor in supporting or hindering sustainability transitions. Clearly, much work remains to be done, at different levels and using various methodologies, to identify and understand the key relationships between sustainability values, attitudes and behaviour, and to apply such knowledge in an effort to "bend the trend" and accelerate the transition towards sustainability (Leiserowitz et al., 2006).

\section{Method}

The study reported here sought to investigate the following: i) Finnish attitudes to energy issues; ii) changes in energy attitudes and the consequences of this; and iii) the process of influencing people's attitudes on energy issues.

In qualitative studies, the aim is to describe particular events, understand certain actions or provide a theoretically meaningful interpretation of observed phenomena (Alasuutari, 1994). This approach enables a more detailed and profound analysis of the phenomenon in question, in contrast to quantitative research, which commonly restricts itself to confirming the existence of the phenomenon. Qualitative research discovers and reveals new information rather than verifying existing statements (Hirsjärvi et al., 2009).

\subsection{Research Questions}

The research questions in this study were as follows:

1) Current situation: What key differences are there among Finnish attitudes to energy issues? Which attitudes would it be desirable to influence most urgently? What is the general position taken in Finnish attitudes to energy issues, how has this changed and how is it changing?

2) Consequences: Is a change in attitudes accompanied by a change in behaviour? What is the pace and direction of changing attitudes?

3) Means of influence: What are the most effective means for influencing people's attitudes? How can people make a difference individually? Who are the major contributors to adverse environmental conditions, and in national terms whose behaviour must be altered most urgently of all in order to minimise environmental damage effectively?

\subsection{Participant}

Energy goals and responsibilities are increasingly being allocated and coordinated in new ways and through a variety of cooperation channels (Micheletti, 2003; Tiihonen, 2004). These networks are interactive and operate at the governmental level (politicians, authorities), collectively (interest groups) and on the markets (companies) (Van Waarden, 1992; Schneider, 1992).

A similar division was used in this study, with the interviewed experts being divided into four categories, including an independent 'free thinker'. Table 1 presents the interviewed experts in terms of their environmental attitude (Group 1 and Group 2) and their role (lobbyist, government, media and free thinker). This same division was also used in a study on future scenarios for Finland's energy policy (Valkila \& Saari, 2010).

A decision first had to be made about the number of study participants. It was decided to select a small number of highly relevant participants working in the Finnish energy sector. The selection of eight interviewees was made so as to ensure representation from all the different parts of the energy sector, which would also ensure that any differences in goals and values would be covered. The expectation in the sampling was to obtain the views of as wide a variety of experts in the energy sector as possible. 
Table 1. Experts interviewed for the study

\begin{tabular}{|c|c|c|}
\hline Role & $\begin{array}{c}\text { Group 1 } \\
\text { Green values (environment) } \\
\text { Nature-centric attitude }\end{array}$ & $\begin{array}{c}\text { Group } 2 \\
\text { Efficiency values (business and industry) } \\
\text { Anthropocentric and techno-centric } \\
\text { attitude }\end{array}$ \\
\hline Lobbyist & $\begin{array}{l}\mathbf{A}_{1}: \text { large, national nature-based interest } \\
\text { group. } \\
\mathbf{A}_{2}: \text { global, effective conservation } \\
\text { organisation. }\end{array}$ & $\begin{array}{l}\text { a: business and labour market policy interest } \\
\text { group representing the electricity and district } \\
\text { heating sectors. }\end{array}$ \\
\hline Government & $\begin{array}{l}\text { B: ministry responsible for parliamentary } \\
\text { debate on energy and for formulation of } \\
\text { future environmental and housing policy. } \\
\text { Aim is eco-efficiency in society and } \\
\text { prevention of adverse changes in the } \\
\text { atmosphere. }\end{array}$ & $\begin{array}{l}\text { b: ministry responsible for Finland's } \\
\text { entrepreneurship and innovation, the } \\
\text { functioning of labour markets and workers' } \\
\text { employability, and development of the regions } \\
\text { in a global economy. Remit includes } \\
\text { formulation of energy and climate policies and } \\
\text { implementation of national coordination. }\end{array}$ \\
\hline Media & $\begin{array}{l}\text { C: independent news and current affairs } \\
\text { magazine based on green values and good } \\
\text { journalistic criteria. }\end{array}$ & $\begin{array}{l}\text { c: Finland's leading business media reporting, } \\
\text { commenting on and analysing economic } \\
\text { events, news, background and so on. }\end{array}$ \\
\hline Free thinker & \multicolumn{2}{|c|}{$\begin{array}{l}\mathbf{x} \text { : an independent public foundation that promotes wellbeing and prosperity in Finnish society } \\
\text { and is subject to parliamentary control. }\end{array}$} \\
\hline
\end{tabular}

The number of organisations in each of the seven categories above, and the number of experts working in each organisation, was first assessed. There were many possible organisations to represent lobbyist groups, media groups and free thinkers, but on the government side there was only the two ministries in question. Within the ministries the experts were randomly selected from the heads of the ministries.

The names of all these experts were written in an Excel table and one name selected randomly from each group. Two more experts were randomly selected from each of the seven groups in case the first or second contact declined to participate in the study. These reserve choices were not required in the end, because all of the experts selected initially were willing and able to take part in the study.

The free thinker selected works for a public foundation which has an explicit agenda. Nevertheless, he was still presented as a free thinker in this study because his work in the energy sector differs significantly from that of other experts, and the main aim of his organisation is to promote prosperity under Government guidance and control in a manner that aims to address the concerns of everybody.

\subsection{Data Collection}

The same themes were discussed with each of the experts, using the same predetermined thematic framework. The framework was designed to approach the research questions in different ways. The thematic framework and the questions are presented below.

(1) Theme: Finnish energy policy in general

a) How would you describe Finland's energy policy?

b) What are the biggest energy threats to Finland?

(2) Theme: current Finnish attitudes towards energy issues

a) How can energy attitudes be measured?

b) What is your view of public attitudes on energy efficiency?

c) What impact do public attitudes have on production and consumption decisions in the energy sector?

d) Are attitudes ecologically motivated, and if so, what are the reliable indicators of this?

e) How do people put into practice their concern for energy saving?

f) How can energy saving be increased in Finland? 
g) Is there a direct link between attitudes and behaviour?

h) Is ethical consumerism a growing trend?

(3) Theme: influencing Finnish attitudes and actions

a) Who is responsible for shaping attitudes?

b) Which organisations have been most effective in supplying people with information on energy issues?

d) How can public attitudes and changes in attitudes be translated into action?

e) What kinds of tools can be used to encourage action?

f) How effectively can individuals help shape public attitudes?

(4) Theme: the future

a) What will the Finnish energy sector look like in the future?

b) In what direction are attitudes likely to develop?

c) What are the main themes evident in today's changing attitudes?

f) Do the attitudes of individual citizens matter?

g) What is the role of public debate?

h) What measures should be taken to meet Finland's energy challenges?

(5) Theme: additional comments

The duration of the interviews ranged from 60 to 120 minutes. Each interview was recorded. In each interview there was one interviewee and one interviewer (one of this article's two authors). Sufficient space was given for interviewees to highlight their own views and those represented by their particular field. The visions of the future put forward by the experts were explored further as necessary.

\subsection{Research and Analysis}

The research material consisted of eight recorded interviews. The discussion produced in each interview situation was transcribed, i.e. the recorded data was converted into verbatim text.

The analysis tool used was the qualitative data analysis software ATLAS.ti. This was used in managing the data accumulated in the study and also at the analysis stage for investigation, comparison and processing.

The study data was analysed using data-based content analysis. This separates out the recurring themes brought up by the study participants (Tuomi \& Sarajärvi, 2003). This process was guided not by information or observations from elsewhere but only by the research questions and the purpose of producing a theoretical understanding of the energy sector. The data was analysed by dividing it into ever smaller components for interpretation. This allowed the most important subject areas to be clearly emphasised. Detailed analysis of this kind improves the assessability and reliability of qualitative data (Mäkelä, 1990).

This method of analysis does not attempt to make inferences about Finnish society at large on the basis of evidence assembled from interviews. However, while the data cannot be said to directly reflect the attitudes of the Finnish public, the views seek to define or expand on different aspects of Finnish attitudes towards energy issues. The selected participants each represented one particular organisation within each of the seven groups referred to above.

The study was based on the premise that, due to the nature of their work, the energy sector experts would have an understanding of public attitudes to energy issues in Finland. The purpose of the analysis was to compare the views of the different experts and to identify connections and contradictions. The results reflect not only the opinions of experts but also views that seek to define or expand on different aspects of Finnish attitudes to energy issues.

\section{Results}

Analysis of the views of the experts interviewed in the study gave rise to the conclusion that influencing attitudes is a dynamic and constantly evolving process. The factors distinguishing different attitudes to energy issues are of key significance, as they not only affect current actions and behaviour but can also influence future changes in attitudes. Attitudes to energy issues must first be analysed and identified before any attempts to influence them can be effectively made. Attitudes can be activated and manipulated with the aid of incentives, rewards and sanctions. Changes in attitudes must then be measured and assessed in order that actions can be further adjusted 
as necessary. The key factors leading to differences in energy attitudes will also themselves be changing over time. This will in turn modify actions and behaviour, thereby influencing attitudes to energy issues, as indicated in the model framework presented here.

\subsection{Discriminating Factors}

\subsubsection{Formation of Attitudes to Energy Issues}

Based on the views of the experts interviewed in the study, Finnish attitudes to energy issues are made up of three components: personal, social and practical. All three of these will influence the nature, permanence and intensity of an individual's attitudes to energy issues.

All the experts presented similar views on the separate factors contributing to people's energy attitudes in Finland. The following factors were identified:

- Unchanging/pre-determined factors: age and sex.

- Self-determined factors: place of residence, political views, industry/occupation, values and attitudes.

- Personal factors: personality, upbringing and peer groups.

The experts stressed the influence of people's age and sex on the formation of their attitudes to energy issues. These factors were seen as the most significant in explaining existing differences in energy attitudes. The increasing concern felt by children and young people over energy issues, and the readiness and willingness of young people to take action were seen as growing trends. There was also a general belief that with the next generation emerging, the negative energy attitudes prevailing currently among men will diminish.

Personal factors include the individual's personality, home upbringing and peer groups. These were seen as being connected with prejudices and fears in regard to energy issues. Personal factors were also considered important in taking responsibility and seeing things through successfully, and were seen as significant motivating factors in action on energy conservation and raising energy efficiency.

In addition to the personal component, the experts noted the importance of the social dimension in influencing the formation of energy attitudes, as an individual's knowledge and skills take shape within a framework of social interaction. They stressed that the social network and culture to which an individual belongs and to which he/she looks for confirmation and direction in regard to energy attitudes play a key role in the formation of attitudes to energy issues.

Based on the study data, it was concluded that there are at least five such social groups observable among Finns. Trailblazers are active in propagating new attitudes and are already operating in a very determined fashion to control climate change. Tomorrow's consumers are mainly young people cooperating closely and following non-materialistic values. They seek to curb climate change specifically through minimal consumption and major energy savings. Rationalists form a large and visible group. These people understand the threat posed by climate change and are looking for rational steps towards long-term energy solutions favourable to all. Neutrals are also a large and visible group. They are aware of the acute threat of climate change but have not yet discovered the means or motivation to act to control it. The final group, sceptics, constitute a small but vocal minority that lives indulgently and denies, or is indifferent to, the threat of climate change.

In addition to the personal and social components, the experts interviewed noted that the practical dimension is a decisive factor in the formation of Finnish attitudes to energy issues. Practical considerations influence not only the formation of energy attitudes but also the way in which these attitudes change. The adoption of new attitudes is often influenced by the energy-saving and energy-friendly models that people learn and rationally judge and select on the basis of their existing views. If individuals perceive their energy-efficiency actions to be worthwhile, their energy attitudes will be reinforced and the practical dimension further activated. Within the social dimension they will also communicate among their own circle of friends and family a positive message in support of curbing climate emissions. If, on the other hand, there is a conflict in the practical dimension (e.g. energy-friendly deeds are not felt to be beneficial), the attitude towards efficient energy use and energy saving may become more negative.

\subsubsection{Existing Attitudes to Energy Issues}

The experts interviewed in the study emphasised that the range of different views on energy issues in Finland is broad. There are a great many different opinions on energy issues, and there are also many adherents to extreme views. On the other hand, there is also a high proportion of 'ordinary' people who are uncertain or uncommitted. Figure 2 is based on the opinions of the experts interviewed and gives a general view of Finnish attitudes to energy issues on a positive-negative and active-passive axis. 


\begin{tabular}{|l|l|l|}
\multicolumn{2}{c}{ High } & \multicolumn{1}{c|}{ Low } \\
\cline { 3 - 4 } Positivity & $\begin{array}{l}\text { Good readiness to act. } \\
\text { Positive attitudes and green } \\
\text { actions constantly increasing. } \\
\text { Improved understanding of } \\
\text { climate issues and their } \\
\text { significance. }\end{array}$ & $\begin{array}{l}\text { Concerned that worry may lead to } \\
\text { debilitating panic. } \\
\text { Uncertainty about future changes } \\
\text { and burdens. } \\
\text { Irritated by ignorance of current } \\
\text { energy issues. }\end{array}$ \\
\cline { 2 - 3 } & $\begin{array}{l}\text { Growing motivation to save } \\
\text { energy. } \\
\text { Shared aspirations to be } \\
\text { self-sufficient in energy. }\end{array}$ & $\begin{array}{l}\text { Slowness in adopting new attitudes } \\
\text { and practices. Great unwillingness } \\
\text { to pay is a source of conflict. Latent } \\
\text { scepticism and aggression become } \\
\text { evident. }\end{array}$ \\
\hline
\end{tabular}

Figure 2. Finnish attitudes to energy issues, analysed using a four-quadrant diagram

Each of the four quadrants of the diagram is representative of a particular segment of society in term of attitudes to energy issues. Currently, many people's energy attitudes are positive but passive (low activity). All of the experts emphasised the positive attitude prevailing in this quadrant, and that the continuing passivity was due to a lack of motivation.

In regard to the way in which attitudes are manifested in concrete actions, there were differences of emphasis in the views of the experts interviewed. Figure 2 presents the comments of the experts. The figure shows the broad theme perceived by each of the experts as being most important in describing people's energy attitudes, and the position on the pessimistic-optimistic axis which they felt appropriately reflects current Finnish attitudes to energy issues.

\subsection{Changes in Attitudes}

\subsubsection{Pace and Direction of Change}

The experts' assessments of the pace and direction of change in Finnish attitudes to energy issues differed significantly. Four categories of attitude change were identified in the analysis, which were given the following names: steady, strengthening, regressive and shifting.

Half of the experts interviewed for the study $\left(\mathrm{A}_{2}, \mathrm{~B}, \mathrm{~b}\right.$ and $\left.\mathrm{c}\right)$ felt that the pace and direction of the change in attitudes were becoming steadily more favourable. The justification for this was the motivation provided by monitoring personal energy use and the awareness of new ways of being energy friendly. It was believed that a more radical pace will be achieved and that attitudes will change dramatically overall, becoming greener within 10 years.

Expert $A_{1}$ felt that the change in public attitudes is strengthening, and that a radical change in attitudes has already occurred. Expert $\mathrm{x}$ also stressed that there has already been a noticeable change in energy attitudes, but felt that the change in attitudes is now regressive, due to the economic downturn, though attitudes would later move slowly in a more environmentally friendly direction.

Interviewed experts $\mathrm{C}$ and a considered that a shift is occurring in both the pace and direction in which Finnish energy attitudes are developing. They were of the view that people's attitudes are becoming more critical and better informed. There will, however, soon be strong resistance to change, which will reorientate energy attitudes in an undesirable, negative direction. Once this reaction has died down though, energy attitudes will again develop in a more positive direction.

\subsubsection{Connection between Attitudes and Behaviour}

The experts presented differing views of how attitudes affect the behaviour of individuals. The focus of analysis was restricted specifically to attitudes on energy issues and to behaviour concerning energy issues.

The views of the experts interviewed regarding the way in which attitudes and changes in attitudes influence individual behaviour were divided into four categories: rational, direct, conflicting and cumulative. The categories are presented below in order of how much support they attracted. In addition, the justification given by each expert is presented. 
The most support was received for the rational link between attitude and behaviour. Three experts $\left(\mathrm{A}_{2}, \mathrm{~B}\right.$ and c) described this rational attitude change as follows:

- "A change in attitudes has a direct influence on behaviour. It's not automatic but takes time to get used to. When people succeed in changing their attitude to energy, they have the potential and motivation to change their behaviour, too. This is a critical point, and society should establish good examples, steering mechanisms and incentives in order that behaviour changes are real and significant." $\left(\mathrm{A}_{2}\right)$

- "You can't change someone's attitude by force. People change their views themselves when there is something that leads them to reassess their own behaviour. If this is done personally, then changes will also be seen in behaviour." (B)

- "People behave rationally, which means that costs and benefits dictate behaviour. Attitudes are formed by weighing up rational options and this then leads to related action being taken." (c)

Two of the experts interviewed ( $a$ and $b$ ) highlighted a direct link between attitude and behaviour, and justified this causal dependency relationship. This was referred to in the study as a direct link.

- "Individuals need an attitude change before they can change their behaviour. That's essential. Only by changing attitudes can people change their behaviour." (a)

- "Attitudes certainly have a direct influence on behaviour. Changes can be depressingly slow, though. When attitudes change, behaviour will change and so will the entire energy consumption system." (b)

Two of the experts $\left(A_{1}\right.$ and $\left.C\right)$ set out reasons for there being an irrational and unpredictable link between attitudes and behaviour. This category was referred to in the study as conflicting.

- "You can't simply modify an individual's attitude. People have to want to change their attitude themselves. After that you need a concrete model illustrating how to act before people will set about altering their own behaviour." $\left(\mathrm{A}_{1}\right)$

- "Attitudes can change easily. But behaviour that ties in with attitudes does not automatically follow. Actions may be very much at odds with attitudes." (C)

One of the experts interviewed (x) referred to another linkage between an individual's attitude and behaviour differing from those above. This view was referred to in the study as cumulative.

- "A change in attitude has no direct effect on a change in behaviour. Instead, the effects are strongly cumulative: the more a person's attitudes change, the greater the changes brought about in behaviour as well. In addition to attitudes, a change in behaviour will also need sufficient impetus or desire to act, before behaviour can change." (x)

\subsection{Manipulation and Activation}

\subsubsection{Critical Attitude Groups}

The opinions of the experts interviewed for the study differed from each other when asked to name a critical group whose energy attitudes are such as to require urgent action to influence them. Three of the experts $(\mathrm{B}, \mathrm{b}$ and $\mathrm{x}$ ) said the energy attitudes of the neutrals group needed to be influenced urgently. People in this group, holding neutral views, are assumed to be interested in energy matters in theory and to be increasingly interested in changes, but are not equipped with the knowledge to act. It was felt that efforts to influence this neutral category en masse would be the most effective.

Other critical groups highlighted by the interviewed experts as being important targets for action to influence energy attitudes consisted of middle-aged men $(\mathrm{C})$, parents of small children $\left(\mathrm{A}_{1}\right)$ and decision-makers $\left(\mathrm{A}_{2}\right)$. Expert a criticised the nature of the question, emphasising that a single critical group cannot be selected, as groups are always heterogeneous, and that it would be most effective of all to influence the energy attitudes of all Finns without discriminating. Expert $\mathrm{c}$ also stressed the global dimension and saw that action in the international sphere would have effects radiating outwards and affecting the attitudes of everyone in Finland, too. All the experts interviewed were nevertheless of the view that hardened sceptics also constituted a group with attitudes that require action to be taken to influence them. This, they noted, is a marginal but vocal group that influences the tone of the debate and its discordant voice should be minimised.

\subsubsection{Most Effective Means for Influencing Change}

All the experts interviewed for the study emphasised that actions pursued by the Finnish Government form the most effective network for influencing people's attitudes. It was felt that Parliament enjoys a significant degree of respect for its authority, that politicians' views attract attention, that decision-makers are able to act effectively, 
and that the media have the opportunity to emphasise matters. Legislation was considered to play an ever more important role on account of the need for stricter controls, incentives and sanctions, and for fair and unbiased action. Economic guidance was viewed as a way of making the desired energy options more affordable to people and for actively guiding people's energy behaviour by means of tax relief and higher taxes.

The other means of influence referred to by the experts consisted of the following five categories: peer groups, information provision, the media, upbringing/education and imagery/visions. These, and the experts who presented them, are given in the list below, along with a brief indication of the main points involved. A summary is also given of the practical measures suggested by the experts in each case, with which people's energy attitudes could be reshaped in the desired direction.

- Peer groups: (experts $A_{2}, C, x$ and $b$ ) peer groups have the greatest credibility; present everywhere in many forms; social interaction and commitment. Practical measures include publicity value of opinion-formers; eco-teams of ordinary people; watchdogs overseeing corporate energy use; energy-friendly corporate culture reflected in households.

- Information provision: (experts $A_{1}, B$ and c) high profile of information provision; extensive forums; themes enter public debate. Practical measures include campaigns; information bulletins; information forums; provision of currently available information and improved access to it; motivation; detailed advice.

- Media: (experts $\mathrm{A}_{2}$ and $\mathrm{b}$ ) high profile of the media; influential; multiple perspectives. Practical measures include succinct discussion of issues; growing role in explaining issues; presentation of different viewpoints.

- Upbringing/education: (expert $A_{1}$ ) easy to coordinate; influencing decision-makers of the future; equitable. Practical measures include formal education; environmental education; civics development; information bulletins in workplaces etc.

- Imagery/visions: (expert a) refining and adjusting views is effective and has a ripple effect. Practical measures include reducing focus on savings; emphasis on the common good; patriotic spirit; vision of a better world.

\subsubsection{Most Important Means for Households}

All the experts interviewed in this study had similar views on the most important means of influence available to households for controlling climate change. The nature of the energy attitudes held by households will determine the how active and intensive their actions are. The means for influencing change are presented in categories grouped according to the particular theme stressed (living, travel and eating decisions), along with a number of separate means referred to by some of the experts interviewed.

According to the experts interviewed, people can make the biggest difference through their living decisions. The size and location of a dwelling are significant factors affecting the household's energy saving. Overall energy consumption, domestic appliances, lighting and the indoor temperature will be of considerable significance. A decision to use 'green' electricity or to reduce use of a holiday home will also be relevant. People can also make a difference with their travel decisions. Favouring public transport (bus, rail, metro, tram), cycling or car-sharing is essential. Reducing private motoring and paying attention to vehicle consumption data, and making any vehicle purchases on the basis of these, are also effective means by which households can influence change. Favouring travel within Finland and minimising flights abroad are also significant factors. The third most significant factor was households' eating decisions, principally decisions concerning vegetarian choices and locally sourced food.

In addition to living, travel and eating decisions, the experts also noted that households can make a significant difference by influencing other people's views, primarily within their own circle of family and friends. Besides sharing opinions, individuals can in practice do a range of other things too: get others to adopt their new practices; participate actively in civic activity; constantly review and update their consumption habits; and expand their own awareness of energy issues (e.g. by making use of organisations advising on energy issues).

\section{Discussion}

The data from this study describes only the attitudes of the experts interviewed and how these energy sector experts perceive the attitudes of the general public. The data does not directly represent the attitudes of the Finnish public. Instead, the views expressed seek to define or expand on different aspects of Finnish attitudes to energy issues. Few details are given here of the interviewees or the organisations in which they work, as such information is not essential for the presentation of the study and because the interviewees all wished to remain anonymous for the purposes of this study.

The results of the interviews suggest that Finnish attitudes to energy issues are considerably fragmented along 
both a positive-negative axis and an active-passive axis. Indeed, no single common description of public attitudes to energy issues was identified in this study. Current attitudes were described as leaning in either a pessimistic or an optimistic direction. The different experts also emphasised different general themes concerning cognition, activeness, readiness for change, and external stimuli/subsidiary effects, with which people's current energy attitudes are intertwined.

The results of the interviews indicate that energy attitudes are shaped and modified in response to events that have personal, social and practical dimensions. The experts interviewed presented conflicting views of the pace and direction of change. They also found that the link between attitudes to energy issues and concrete behaviour is not easy to determine. The link was seen variously as rational, direct, conflicting and cumulative. 'Neutrals' were highlighted as a critical group whose energy attitudes should be influenced urgently. The most effective practical network was considered to be the country's political leadership, and the key means of influencing change were peer groups, information provision, the media, upbringing/education and reshaping of imagery/visions. In addition, household decisions regarding attitude and behaviour in respect of living, travel and eating were viewed as significant.

The study collected information from Finnish experts in the energy sector. These experts were divided into four groups on the basis of the organisations they represented (lobbyist, government, media, free thinker). The results did not indicate that the group to which the expert belonged had any direct effect on the nature of the views expressed. The experts interviewed thus mainly represented themselves personally rather than their employer.

The reliability of the study was further enhanced by having verbatim transcriptions made of the interviews and by the analysis of these as a block of data. The interview framework was constructed systematically and room was allowed in the interview for any additional comments that the interviewee wished to make. The experts interviewed represented a wide variety of different entities dealing with energy issues in Finland.

The study gave rise to some interesting topics for further research and for more detailed examination. Increasing the number of experts interviewed may also further refine the results and bring out new ideas. Conducting a similar survey in another country would allow for comparison in order to ascertain any country-specific differences. It would also be appropriate to study in more detail the categories and groupings formed in this study and the way they function in practice. For instance, focusing on the means of influence considered to be the most effective in altering people's attitudes and measuring the success of this would provide information on the practical application of these means of influence. This study also provides material for further research on people's opinions and on analysing individual attitudes to energy issues and their impact.

In all, the study has offered a new approach to understanding people's attitudes to energy issues and the impact of these attitudes by documenting the views of a selection of the country's energy sector experts as individuals. The study results supported the expectations of the authors and the results of previous studies in regard to attitudes and their impact and the role of personal identity and individual circumstances. Although the scope of analysis within the study framework was restricted to the attitudes of a specific group of people (the Finnish population) towards a single theme (energy), the results support those obtained in broader contexts in regard to the complexity of the linkages. Overall, the devising of a schematic representation illustrating attitudes and influences and recognition of the many factors involved in hastening and slowing the process was considered a vital new insight of significant interest.

\section{References}

Aho, I., Kosonen, R., Hoving, P., Marttila, M., Pirinen, A., Speeti, T., \& Haajanen, J. (2006). Energy management in apartment blocks and office buildings: A guide for property management and maintenance companies. Espoo: VTT Technical Research Centre of Finland, Fact Sheets 1737.

Alasuutari, P. (1994). Qualitative Research. Tampere: Vastapaino.

Allard, E. (1983). Sociology 1. Helsinki: WSOY.

Attalla, A., \& Carrigan, M. (2001). The myth of the ethical consumer - do ethics matter in purchase behaviour? Journal of Consumer Marketing, 18(7), 560-577. http://dx.doi.org/10.1108/07363760110410263

Auger, P., \& Devinney, T. (2007). Do what consumers say matter? The misalignment of preferences with unconstrained ethical intentions. Journal of Business Ethics, 76, 361-383. http://dx.doi.org/10.1007/s10551-006-9287-y

Bergström, S., \& Leppänen, A. (2007). Customer Marketing. Helsinki: Edita.

Blake, J. (1999). Overcoming the 'value-action gap' in environmental policy: Tensions between national policy 
and local experience. Local Environment, 4, 257-278. http://dx.doi.org/10.1080/13549839908725599

Blowfield, M., Erdenechimeg, R., \& Tallontire, A. (2001). Ethical consumers and ethical trade: a review of current literature. United Kingdom: Policy series 12, Hobbs the Printers.

Brand, K-W. (1997). Environmental Consciousness and Behaviour: The Greening of Lifestyles. In Redclift, M., \& Woodgate, G. (Ed.), The International Handbook of Environmental Sociology (Cheltenham: Edward Elgar), pp. 204-217.

Burgss, J., Harrison, C., \& Filius, P. (1998). Environmental communication and the cultural politics of citizenship. Environment and Planning A, 30(8), 1445-1460. http://dx.doi.org/10.1068/a301445

Darby, S. (2006). The Effectiveness of Feedback on Energy Consumption: A Review for DEFRA of the Literature on Metering. Oxford: The Environmental Change Institute, University of Oxford.

Dearing, A. (2007). Enabling Europe to Innovate. Washington: American Association for the Advancement of Science.

Dennett, D. (1991). Consciousness Explained. Boston: Little Brown.

Eden, S. (1993). Individual environmental responsibility and its role in public environmentalism. Environment and Planning A, 25(12), 1743-1758. http://dx.doi.org/10.1068/a251743

Eisler, A., Eisler, H., \& Yoshida, M. (2003). Perception of human ecology: Cross cultural and gender comparisons. Journal on Environmental Pychology, 23, 89-101. http://dx.doi.org/10.1016/S0272-4944(02)00083-X

Erwin, P. (2001). Attitudes and Persuasion. Helsinki: WSOY.

European Commission. (2008). EU action against climate change: Leading global action to 2020 and beyond. Luxembourg: Office for Official Publications of the European Communities.

Gallup Finland. (2009). Finnish Attitudes to Climate Change and to Ways of Combating it. Helsinki: Gallup Finland.

Haapala, J., \& Aavameri, L. (2008). The Conscience Economy. Helsinki: Talentum.

Harrison, C., Burgess, J., \& Filius, P. (1996). Rationalizing environmental responsibilities. Global Environmental Change, 6(3), 215-234. http://dx.doi.org/10.1016/0959-3780(96)00016-7

Hinchliffe, S. (1996). Helping the Earth begins at home: The social construction of socio- environmental $\begin{array}{llll}\text { responsibilities. } & \text { Global }\end{array}$ http://dx.doi.org/10.1016/0959-3780(95)00113-1

Hawthorne, M., \& Alabaster, T. (1999). Citizen 2000: Development of a model on environmental citizenship. Global Environmental Change, 9, 25-43. http://dx.doi.org/10.1016/S0959-3780(98)00022-3

Hirsjärvi, S., Remes, P., \& Sajavaara, P. (2009). Study and Write. Helsinki: Tammi.

Iwanow, H., Jeffrey, A., \& McEachern, M. (2005). The influence of ethical trading policies on consumer purchase decisions: A focus on GAP Inc. International Journal of Retail \& Distribution Management, 33(5), 371-387. http://dx.doi.org/10.1108/09590550510596740

Kollmuss, A., \& Agyeman, J. (2002). Mind the gap: Why do people act environmentally and what are the barriers to proenvironmental behaviour? Environmental Education Research, 8, 239-260. http://dx.doi.org/10.1080/13504620220145401

Kuisma, J. (2001). Journey to a Greener Society. Helsinki: Statistics Finland.

Kuisma, M. (2004). Prospects for using technology in environmental issues. Environment and business. In Heiskanen, E. (Eds.), Environment and business (pp.246-255). Helsinki: Gaudeamus.

Leiserowitz, A., Kates, R., \& Parris, T. (2006). Sustainability values, attitudes and behaviors: A review of multinational and global trends. Annual Review of Environment and Resources, 31, 413-44. http://dx.doi.org/10.1146/annurev.energy.31.102505.133552

Lorenzoni, I., \& Pidgeon, N. (2006). Public Views on Climate Change: European and USA Perspectives. Climatic Change, 77, 73-95. http://dx.doi.org/10.1007/s10584-006-9072-z

Lybäck, K. (2002). Environmental issues at the everyday micro-level: Conflict between attitudes and behaviour. In Loukola, T. (Eds.), Values, Environment and Technology: new Justifications for Social Actions (pp.215-276). Helsinki: University Press. 
Massa, I., \& Haverinen, R. (2001). Environmental policy for everyday life, a preliminary study. Helsinki: Suomen ympäristö 521, Ministry of the Environment.

Micheletti, M. (2003). Political Virtue and Shopping. Individuals, Consumerism, and Collective Action. Basingstoke: Palgrave Macmillan. http://dx.doi.org/10.1057/9781403973764

Mikkola, T. (2001). Environmental values and attitudes of the new middle class as a reflection of changes in world view. In Helve, H. (Eds.), Values, World View and Gender (pp. 95-139). Helsinki: University Press.

Moisander, J. (1996). Attitudes and ecologically responsible consumption. Helsinki: Research Notes 218, Statistics Finland.

National Research Council. (1999). Our Common Journey. Washington: National Academies Press.

Neergaard, P., \& Pedersen, E. (2006). Caveat Emptor - Let the buyer beware! Environmental labelling and the limitations of "green" consumerism. Business Strategy and the Environment, 15, 15-29. http://dx.doi.org/10.1002/bse.434

Oktay, Z., \& Dincer, I. (2009). Exergoeconomic analysis of the Gonen geothermal district heating system for buildings. Energy and Buildings, 41, 154-163. http://dx.doi.org/10.1016/j.enbuild.2008.08.003

Omer, A. (2008). Energy, environment and sustainable development. Renewable and Sustainable Energy Reviews, 12, 2265-2300. http://dx.doi.org/10.1016/j.rser.2007.05.001

Peattie, K. (2002). Environmental Marketing Management. London: Financial Times Management.

Rannikko, P. (1995). Environmental awareness and environmental conflicts. In Järvikoski, T., Jokinen, P., \& Rannikko, P. (Eds.), Perspectives on environmental sociology (pp. 65-91). Turku: Publications of the University of Turku's further education and training centre.

Retallack, S., Lawrence, T., \& Lockwood, M. (2007). Positive Energy. Harnessing People Power to Prevent Climate Change. London: IPPR.

Ruostetsaari, I. (2010). Changing Regulation and Governance of Finnish Energy Policy Making: New Rules but Old Elites? Review of Policy Research, 27, 273-297. http://dx.doi.org/10.1111/j.1541-1338.2010.00442.x

Sairinen, R. (1996). Finns and environmental policy. Helsinki: Research Notes 217, Statistics Finland.

Schneider, V. (1992). The structure of political networks: A comparison of the 'chemical control' and 'telecommunications' policy domains in Germany. European Journal of Political Research, 21, 109-129. http://dx.doi.org/10.1111/j.1475-6765.1992.tb00291.x

Sippola, A-R. (2009). Ever fewer Finns are willing to pay for environmental protection. Helsingin Sanomat, 8.10.2009(A), 4 .

Soyhan, H. (2009). Sustainable energy production and consumption in Turkey: A review. Renewable and Sustainable Energy Reviews, 13, 1350-1360. http://dx.doi.org/10.1016/j.rser.2008.09.002

Stern, P. (2000). Toward a coherent theory of environmentally significant behavior. Journal of Social Issues, 56, 407-424. http://dx.doi.org/10.1111/0022-4537.00175

Suhonen, P. (1994). Media, people and the environment. Helsinki: Hanki ja Jää.

Thøgersen, J., \& Crompton, T. (2009). Siple and Painless? The Limitations of Spillover in Environmental Campaigning. Journal of Consumer Policy, 32, 141-163. http://dx.doi.org/10.1007/s10603-009-9101-1

Tiihonen, S. (2004). From Governance to Governance. A Process of Change. Tampere: University Press.

Tikka, P., Kuitunen, M., \& Tynys, S. (2000) Effects of educational background on students' attitude, activity levels, and knowledge concerning the environment. The Journal of Environmental Education, 31(3), 12-19. http://dx.doi.org/10.1080/00958960009598640

Tulokas, R. (2004). Environment statistics 2004. Helsinki: Environment and natural resources, Statistics Finland.

Tuomi, J., \& Sarajärvi, A. (2003). Qualitative research and content analysis. Jyväskylä: Gaudeamus.

Uusitalo, L. (1991). Personal benefit or the public good? Conflict between environmental awareness and action. In Massa, I., \& Sairinen, R. (Eds.), The environment issue: Environmental threats as a challenge to society (pp. 24-48). Helsinki: Gaudeamus.

Uusitalo, O., \& Oksanen, R. (2004). Ethical consumerism: A view from Finland. International Journal of Consumer Studies, 28(3), 214-221. http://dx.doi.org/10.1111/j.1470-6431.2003.00339.x 
Valkila, N., \& Saari, A. (2010). Urgent need for new approach to energy policy: The case of Finland. Renewable Sustainable Energy Reviews, 14, 2068-2076. http://dx.doi.org/10.1016/j.rser.2010.03.039

Van der Horst, D. (2007). NIMBY or not? Exploring the relevance of location and the politics of voiced opinions in renewable energy siting controversies. Energy Policy, 35, 2705-2714. http://dx.doi.org/10.1016/j.enpol.2006.12.012

Van Waarden, F. (1992). Dimensions and types of policy networks. European Journal of Political Research, 21, 29-52. http://dx.doi.org/10.1111/j.1475-6765.1992.tb00287.x 